\title{
A critical analysis of anarchist critiques of the Field of "Solidarity and Cooperative Economy" in Greece
}

\author{
Vaggelis Gkagkelis ${ }^{1 *}$ \\ ${ }^{1}$ Aristotelian University of Thessaloniki, Thessaloniki 541 24, Greece
}

\section{KEYWORDS}

Anarchism movement

Autonomy

Self-management

Solidarity and

Cooperative Economy

\section{ABSTRACT}

In this article, we explore the critiques developed by the anarchist social movement towards the "Solidarity and Cooperative Economy" in Greece. Initially, we outline the genealogy of the structural connection governing the "solidarity" economy with the development of contemporary social movements worldwide. Then, through the indexing of anarchist publications, we proceed to focus on two main anarchist critiques emphasizing on the economic and political problems of a "solidarity" economy which, in turn lead to the construction of the political position that refutes the interrelation of social movements with the field of alternative economy. We also outline the economic and political theory of classic anarchist thinkers: Kropotkin, Proudhon and Bakunin and we reappraise the critiques of the contemporary Greek anarchist movement based on these thinkers. Ultimately, the paper seeks to detect the points of convergence between the "Solidarity and Cooperative Economy" and contemporary anarchist movement. Deeming the practice of self-management as the principal interface between the anarchist thought and the organisation of networks and communities that constitute the "Solidarity and Cooperative Economy", the present article calls for reflection and re-evaluation of these critiques with the ultimate objective being the delineation of new areas of political antagonism with capitalist structures and social change.

\footnotetext{
* Contact address: gkagkelis@polsci.auth.gr (V. Gkagkelis)
} 


\section{Introduction}

With the term "Solidarity and Cooperative Economy" (SCE), we define the set of economic activities in the field of production, trade, commerce, and consumption seeking to place its primary focus on people and the planet. Essentially, depending on the circumstances this may be a strategic and planned collective venture or it may be a type of organised labour that individuals opt for due to socio-economic circumstances (e.g. unemployment). In both cases, it includes a wide range of economic practices that are in line with basic humanistic values. The conceptual ambiguity surrounding this form of alternative economy creates a rather hazy landscape reflected both in the literature of legal, political and sociological sciences and the discourse that develops within the informal networks of activists. This ambiguity extends to issues concerning the interplay of social movements and the solidarity economy.

This paper explores the relationship of solidarity economy ideas with the anarchist movement which is one of the most dynamic social movements in Greece. We will try to identify the main lines of economic and political critiques of the anarchist movement towards alternative economic activities and actions. The present text makes use of the term "Solidarity and Cooperative Economy" (Psimitis 2016) in an attempt to properly define this field of political and commercial activities which refers to forms of alternative social practices that seek radical transformation of everyday life in a horizontal manner. At the same time, the text adopts the view that the alternative economy is a key implement for the development of modern radical movements (Böhm, Dinerstein, and Spicer 2010; Zaimakis 2018). This cooperative concept combines mild forms of economic activity around the main axes of direct democracy, solidarity and autonomy (Alarcon and Sato 2019; Gritzas and Kavoulakos 2016; Polleta 2014). In other words, it is a participatory process that places the prefigurative transformation of the economy at the basis of social relations and, thus, introduces and reinforces conditions that are antagonistic with the capitalist economy. 
This line of thought challenges the term of "social economy" promoted by the State, international organizations and institutions, and their policies and is part of the so-called "third sector" (Moulaert and Ailenei 2005). In that case, the cooperative schemes that comprise it are characterized as "social enterprises". Through the process of making funding available or withholding it, these enterprises are kept in a state of continuous evaluation in terms of their innovation, entrepreneurship and financial viability.

It is worth highlighting here that the term "social economy" is itself superfluous, because the two verbal elements used to formulate it refer to similar meanings. In particular, the word "economy" originates from the ancient Greek language and, more specifically, is the combination of the words "oĩkos" (house) and "vغ̇uouaı" (allot), which means the management of the house. Officially, the term "economy" refers to a set of systematic human actions found in organized societies including production, distribution, exchange, and consumption of goods and services. Hence, any economy is a social activity, but the term "Solidarity and Cooperative Economy", enriches and specifies this particular set of economic activities with a particular kind of ethics and politics of an antagonistic economy.

Specifically, the practices of SCE can be viewed through as a global movement with a long history and tradition putting its focus on the form of the economic symbiotic cooperation (RIPPES 2015). There is a vast diversity and pluralism of these practices around social and political organization that differs from the capitalist practices which are only the tip of the iceberg (Gibson-Graham 2014; 2008; 1996). According to Gibson-Graham (2014; 2008; 1996), there are many non-capitalist economic practices that exist alongside capitalist practices. The alternative economic relations emerging from SCE include a wide range of social activities such as production, exchange and consumption and attempt- through the ethics of solidarity- to resist the dominant form of capitalist barbarism that is based on the exploitation of labour and the accumulation of capital (Gritzas and Kavoulakos 2016). 


\section{Theoretical framework}

\subsection{The historical relationship of the "Solidarity and Cooperative Economy" with the social movements}

Although collective forms of work organisation are directly linked to the history of mankind, examples of cooperative economics appear in Europe as early as the period of the Industrial Revolution. Especially since the middle of the 18th century onwards, in a social environment of mass unemployment and poverty and non-existent labour rights, the first organised cooperative ventures are developed in France, England, Germany and North America. These cooperative formations were directly associated with the activities of the emerging working class of that period, who attempted to construct an alternative to the structural inequalities of the emerging industrial capitalism (Shaffer 1999).

With the arrival of the 20th century, cooperatives, mostly agricultural, were introduced in the state policies and planning, according to the needs and the different stages of economic development (Chloupkova 2002). The basic incentives for the establishment of cooperative structures were the acquisition of bargaining power by the respective producers, the control of the supply of agricultural products and the avoidance of unfair speculation (Kontogeorgos and Sergaki 2016). At the same time, cooperatives were a means of agrarian and economic reform attempted by the revolutionary governments that faced the problem of large-scale land ownership. Through the collectivisation of land, the cooperative logic was expressed (to a lesser or to a greater extent) in the Mexican Revolution (1910), the Russian (1905) and the October Revolution (1917), in Hungary (1919), in the rural collectives of the Spanish Revolution (1936-39), in Yugoslavia (1948), in the Chinese Revolution (1949) and in the Cuban Revolution (1958) (Novaes 2013).

However, the cases that seem to inspire and shape modern thinking with regards to "Solidarity and Cooperative Economy" are those springing up in Europe and the United States from the late 1960s onwards (D'Anieri et al. 1990). The post-war period stands as a historic milestone, with the new 
welfare states, protests and collective action culminating on a global level and, simultaneously, collective subjects that remained in obscurity until that point being brought to the fore.

From the mid-1950s onwards, profound social changes were being incubated through various developments; from the anti-war movement, the civil rights movement in the USA, May 1968 uprising in France, the student protests in Germany, Britain and Mexico, to the "Hot Autumn" workerstudent unions strike in Italy, the movements for the establishment of democracy in various parts of the world, from Francoist Madrid to communist Prague, the development of critical Catholicism from Latin America to Rome, the first signs of the second feminist wave, and the environmental movements, all could be thought to have a catalytic role in the policies implemented in the 1970s.

Newly emerging social movements during the period of 1960 and 1970 focused on social change through issues of social identity, culture and daily life, while moving away from traditional movements that emphasised the economic field (Bosi et al. 2016; Jasper 2010; Novy and Colomb 2013). Issues such as the social construction of gender and sexuality dynamically emerged in the public sphere (Somerville, 1997: 689). At the same time, new semantic frameworks of the social world enabled distinct social groups and social categories to express particular demands, in the context of a wider democratisation movement (Seferiadis 2006,10). These complex realities of the emerging collective subjects tend to oppose the dominant institutions, with the main goal of reforming or radically transforming them (Tilly 2007,34). But it also needs to be noted that their degree of political engagement depends on broader social and political factors (Psimitis 2011, 29).

In this context, since the mid-1960s, practices of SCE have been placed under the general spectrum of redetermination of economics and politics by social movements (Gaiger 2017). The development of the concept of selforganisation and direct participation revealed a new environment of collective action that moved away from the view that social and political change come through the acquisition and occupation of political power. 
In some of the circles of these new social movements, the primary focus is placed on quality of life, daily social practices, participatory democracy and autonomy, while, simultaneously, they strongly criticise the dominant conceptualisation of labour (Laville 2010). From 1967 to 1977, following extensive strike mobilisations, many cases of occupation of corporations and factories can be observed, in which the workers attempt to highlight the autonomy of the working class from capitalism on a political level (Fuller, 2001). Typical examples of that time are the struggles to recognise factory boards as the workers' means of controlling the production process itself during the Italian "Hot Autumn" period (1968) and the occupation of the LIP watch factory in France (1973-1974).

However, it is worth noting that, since the early 1980s, both in Europe and the United States, a process of integrating these antagonistic ventures into the establishment has been taking place (Kavoulakos and Gritzas 2015). The collective experiments that did not perish in the short term began to gain public recognition, to develop institutional mechanisms, to have access to decision-makers, and to take advantage of the available material resources (Della Porta 2020). The phenomenon of the transition of social movements towards the commercialisation of their social activities in services (Jacobsson and Saxonberg 2013) until the 1990s in Europe, USA, Asia and Africa, takes place in parallel and due to the transformation of the urban/local governance brought about by neoliberalism, creating new ways of thinking about the private and public interest (Kavoulakos and Gritzas 2015).

Reaching the end of the $20^{\text {th }}$ and the beginning of the $21^{\text {st }}$ century, the emergence of the movement against neoliberal globalisation highlighted the social consequences of the neoliberal free market policies and the collapse of the welfare state. At the same time this movement, which was born on the streets of Seattle during protests against the World Trade Organization (WTO) conference in 1999, developed rapidly as a multifaceted protest movement criticising the basis of the neoliberal ideology (Andrena and Della Porta 2003; Bandy and Smith 2005). 
In particular, the main features primarily forming the struggle against the neoliberal globalisation were the return of politics to the streets, through transnational forms of protest, and the focus on immediate action, through processes of repoliticalisation of meanings (Della Porta 2020; 2005). This dual dimension of the movement provided ways of networking and creating events of an alternative and a "bottom-up" globalisation (Bandy and Smith 2005; Della Porta and Tarrow 2005).

In this historical context, radical cooperative economic efforts started to be established based on the generalised model of self-management of recovered companies in Argentina, beginning during the 1990s and peaking after the economic collapse of the country in 2001. The phenomenon of recovered companies in Argentina has highlighted a state of a transition of labour struggles towards the creation of an autonomous labour movement with diverse characteristics (Ruggeri and Vieta 2015; Ruggeri 2014). On the other hand, the establishment of the Good Governance Councils by the indigenous tribes of Mexico in 2003 played a decisive role in the development of the modern radical cooperative movement, mainly through a movement of solidarity networks. This particular form of political and social organisation is based on horizontality and attempts to resolve the demand for land redistribution and autonomy in the Zapatista community in the Chiapas region southeast of Mexico.

Finally, news coming from the Rojava region in northern Syria highlight the fact that, among other things, the cooperative economy can play a key role in the gradual dissolution of the bureaucratic nation-state.

\subsection{The Solidarity and Cooperative Economy in Greece}

The Ampelakia Village cooperative (Common Union) in Thessaly, in the 18th century, inaugurated the Greek cooperative tradition, while the enactment of the first law (602/1915) for cooperatives in the early 20th century marked the rapid development of agricultural cooperatives. During the 1980's and 1990's, the constant interventions of the State and party agents in the cooperatives' institutional and legal framework created a relationship of dependence with 
degenerating effects on their organisational and social characteristics (Kontogeorgos and Sergaki 2015, 30).

However, the landmark year for contemporary cooperativism in Greece is 2004. The beginning of the 21st century finds Greece in a period of rapid economic growth. This growth is driven by the holding of the Olympic Games in 2004, the public investments in major projects preceding the Games, in reforms and in phenomena of middle-class investment ventures and consumerism in Greek society.

Counterbalancing this, it is worth noting the 2003 European Union Summit held in Thessaloniki. This was the moment when the presence of the Anarchist and Anti-authoritarian movement makes its presence felt in the first mass participation in the protest events of the movement for a global justice (anti-globalisation movement) (Kanelopoulos 2020, 191). Within the ranks of the anti-globalisation movement, both internationally and domestically there was a trend which was inspired by the Zapatistas movement and promoted alternative logics of political, economic and social organisation (Raynaud 2008).

In this direction, the fair-trade cooperative "Sporos" (meaning "seed") was created in 2004, which operated using alternative ways of direct political and social action. Starting from fair and solidarity trade, the activists and members of "Sporos" sought to ground their political wish for a "new world". From 2004 to 2012, when it completed its operations, Sporos cooperative was a collective that aimed at practical solidarity with other domestic and international collectives, social movements and peoples of the so-called "Global South". From the first years of its creation, it created an autonomous network for the distribution of products from organised movements struggling to free themselves from local intermediaries and large corporations. Indicative examples of this kind of movements were the Zapatista's coffee cooperatives, the Cooperativa "El Ceibo" of Bolivia, the Landless Workers' Movement of Brazil (Movimento dos Trabalhadores Sem Terra, MST), the "Adivasi" movement and other producers in India. Finally, it 
supported individual producers and collective initiatives for the production of goods in Greece.

The following years, various self-organising initiatives began to spring up in more and more areas of daily life. Radical ideas of autonomy and selforganisation spread explosively and exponentially after the 2008 uprising in Greece, following the murder of the 15 year old student Alexandros Grigoropoulos by a police officer in the Exarchia area of central Athens (Kavoulakos and Gritzas 2015, 340). The main protest events and the insurrectionary and confrontational forms of collective action that lasted for a month in major cities in Greece were followed by a wave of social mobilisation that took the form of squats and social self-managed spaces such as the cases of "Navarino Park", "Cyprus and Patissia Park" and "Agros, self-manageed occupied land" in Athens during the first months of 2009. These initiatives focused on challenging the dominant mode of urbanisation which is based on commodifying public space (e.g. creating private parking areas where there were parks) and accumulating financial capital. Also, these initiatives highlighted a range of social issues focusing on alternative modes of participatory governance based on horizontal and democratic processes.

Two years after the 2008 uprising, in 2010, in the context of the global financial crisis, the Member States of the European Union, with the help of the International Monetary Fund (IMF), are designing crisis management mechanisms for Member States that are unable to meet their public debt repayment obligations. Within this framework, Portugal, Ireland, Cyprus and Greece signed memoranda of financial support in the form of a loan while committing themselves to implementing structural reforms dictated by the IMF, the European Union and the European Central Bank. The imposed austerity policies have rapidly affected the public and private sectors of these countries, because of changes in public policy, the welfare state and labour relations.

In Greece, despite the fiscal measures adopted, the unsustainability of the economy will lead to the imposition of a new memorandum within a short 
time after the first one, paving the way for a crisis that is no longer only economic, but is taking on social, humanitarian and political characteristics.

In response to this vicious cycle of austerity politics, another cycle of protest enriched with alternative forms of collective action appeared (Malamidis 2018; Steinhilper and Malamidis 2016; Souzas and Iliopoulos 2015). During the period 2010-2015, a more general challenge to the consolidation of neoliberal policies was expressed through mass protests, conflicting collective actions and square occupations (the Indignados movement).

However, since 2012, with the decline of dynamic and mass protests, alternative collective actions focusing on solidarity have emerged providing services to those who didn't have access to them informally. These include a multitude of initiatives in a wide range of social activity and which include free clinics, education initiatives, collective kitchens, producer markets, time banks, exchange networks, self-managed cooperative enterprises, etc. The above initiatives were formed by groups of activists who actively participated in the protest events of the previous period (Kavoulakos and Gritzas 2015,345) and are now trying to propose alternative ways of social existence and organisation based on solidarity, self-organisation and direct democracy. Part of this creative resistance (Varkarolis 2012) employs the establishment of cooperative enterprises forming a dynamic environment of the new wave of cooperativism (Vieta 2010).

In 2010, the first workers' collective in Greece is established called "Pagkaki" meaning "bench". The term worker's collective is also coined by this group differentiating their initiative from others in the field. In 2011, "Syn Allois" meaning "with others" becomes a cooperative that imports fair trade coffee and generally is involved with fair and solidarity trade. Most of the members of the two cooperatives come from the aforementioned "Sporos" Cooperative. Soon, several new workers' cooperatives appear in Athens, Thessaloniki and Rethymno, while later we have cooperative enterprises in other cities in Greece. 
The vast majority of all of these ventures are characterised by egalitarian work organisation and decision making, while also not aiming for business profit. Furthermore, many events were organised with the aim to help similar projects to start, to initiate collaborative networks and to disseminate their philosophy and practices regarding the organisation of collective labour.

In 2013, the workers and employees of VIOME, a soap and detergent factory in Thessaloniki that filed for bankruptcy in 2011, took over the factory (Malamidis 2018). The VIOME workers' struggle, on the one hand gave great momentum to the field of Solidarity and Cooperative Economy, emphasising an alternative proposal for organising work without bosses, for developing productive capacities without hierarchical structures, and on the other hand it broadened the debate on the relationship that the alternative economy can have with the elaboration of new strategies for collective action.

\section{Methodological considerations}

Main critiques anarchist critiques regarding the "Solidarity and Cooperative Economy"

The critiques developed with regards to "Solidarity and Cooperative Economy" trace their origin to a rather limited literature. Analysing and problematising these critiques offers the opportunity of a deeper understanding of the interaction between contemporary social movements and direct-action practices in relation to the economy and production. At the same time, the attention that SCE initiatives have received might aid the social movements themselves in redefining their relationship with alternative repertoires of collective action providing a whole new dimension to the issue of social and political change.

The research presented here is based on the analysis of articles from six anarchist/anti-authoritarian/libertarian publications in the period 2012-2014. Table 1 shows a list of the publications where the data was collected from. 
Table 1. List of indexed publications

\begin{tabular}{|c|c|c|c|}
\hline $\begin{array}{c}\text { Type of } \\
\text { publication }\end{array}$ & Author & Title & Year \\
\hline 1) Public text & $\begin{array}{l}\text { Thersitis, Area of } \\
\text { intrigue and } \\
\text { overthrow } \\
\text { [Collectivity] }\end{array}$ & $\begin{array}{l}\text { A text criticizing the } \\
\text { solidarity economy }\end{array}$ & 2014 \\
\hline $\begin{array}{l}\text { 2) Newspaper: } \\
\text { Freedom Route }\end{array}$ & Eleutherokokkos & $\begin{array}{l}\text { Alternation: } \\
\text { Another world is } \\
\text { not possible! }\end{array}$ & 2014 \\
\hline $\begin{array}{l}\text { 3) Text of } \\
\text { Libertarian Trade } \\
\text { Union (E.S.E)- } \\
\text { Thessaloniki } \\
\text { speech at the } \\
\text { pan-Hellenic } \\
\text { conference of the } \\
\text { organization }\end{array}$ & $\begin{array}{l}\text { Libertarian Trade } \\
\text { Union (E.S.E), local } \\
\text { organization of } \\
\text { Thessaloniki }\end{array}$ & $\begin{array}{l}\text { Regarding the } \\
\text { alternative } \\
\text { economy }\end{array}$ & 2014 \\
\hline $\begin{array}{l}\text { 4) Newspaper: } \\
\text { Contra }\end{array}$ & $\begin{array}{l}\text { Newspaper } \\
\text { editorial team of } \\
\text { Contra }\end{array}$ & $\begin{array}{l}\text { Self-management: } \\
\text { Labour Liberation } \\
\text { or another bait for } \\
\text { the Capitalist trap? }\end{array}$ & 2013 \\
\hline 5) Public text & $\begin{array}{l}\text { Workers and } \\
\text { Unemployed } \\
\text { from the book } \\
\text { domain (WaU) }\end{array}$ & $\begin{array}{l}\text { Are meanings } \\
\text { relativised in dark } \\
\text { times? A critical } \\
\text { approach to self- } \\
\text { managed ventures }\end{array}$ & 2013 \\
\hline 6) Public text & $\begin{array}{l}\text { Partnership for } \\
\text { Anarchy (Pf A) }\end{array}$ & $\begin{array}{l}\text { Let's deny that } \\
\text { it belongs to } \\
\text { domination because it } \\
\text { destroys what is } \\
\text { beautiful in the world } \\
\text { (Acritique of self- } \\
\text { management) }\end{array}$ & 2012 \\
\hline
\end{tabular}

Through the methodological approach of discourse analysis, the study attempts to showcase the critical discourse that has developed from the anarchist movement while delineating its physiognomy on the issue of anticommodity action as it was formed in Greece from 1974 onwards. It is worth noting that discourse analysis of printed archival material clearly offers a view 
of the position and meaning expressing a historical point in time and the dynamics around it as opposed to interviews that retrieve memories through the lens of the present. The archival material captures a public stance within a historical time in which the action is produced. Under this light, the selection of archival material from the period of 2012-2014 was made because, during this period and in response to material and social deprivation due to the economic crisis, there was an increasing spread of cooperative enterprises observed throughout Greece. Within activist circles, discussions and reflections emerged about the role that cooperative ventures can play in the context of social change. On the one hand, SCE is viewed with scepticism both by leftist organisations and by anarchist collectives and, on the other hand, there were many cases in which it was attempted to integrate alternative economy very quickly.

The archival material of the six anarchist/anti-authoritarian/libertarian publications is a representative sample of the discourse that prevailed regarding SCE from a part of the anarchist collectives in Greece. Their critique is situated around the political dimension of participation in a cooperative enterprise.

In fact, as SCE attempts to stand as the alternative proposition to the dominant economy through experimentation, it has often been criticised by radical anti-capitalist groups. These critiques represent groups of anarchists and the wider left in Greece taking either a public or an informal position on the issue; they seem to have construed SCE in a way that disregards any potential connection and influence between radical social movements and SCE.

This political stance seems to be related to specific circumstances in which the anarchist movement in Greece was formed during the first years of the regime change since 1974. These special characteristics hold true to this day. Namely, Nikos Souzas (2015) in his study on the anarchist movement in Greece focuses on the cultural fermentation and state repression during the 80 's, which determined its course to a large extent. Through practices such as occupying buildings, the "Do It Yourself" (DIY) culture, the punks' concerts, 
independent venues and the production of printed material, we can see that anti-hierarchy and anti-commodification were key factors in the semantic framing of activist groups. The structural link between anti-hierarchy and anti-commodification was essentially an experiment in direct democracy and direct action, in an attempt to highlight aspects of post-capitalist social life.

Within this framework of thought, the emphasis on anticommodification relations as a way of distinguishing oneself from the dominant capitalist mode of organisation has the effect of perceiving the economy as an exclusively capitalist activity. Within the framework of the anti-institutional/anti-state project, the economy is not perceived as a field in which activist intervention is beneficial, but that it needs to be transcended. Essentially, this is a logic that attempted to challenge the dominant commodification and individualisation culture that was growing fast during that time in Greece. The practices of anti-commodification focused on the critique of the commodification of everyday life that included a range of issues such as housing, communication, and expression. In this context, within the occupied spaces, the strategy of the abolition of the commodity trade was followed as a way of directly challenging the dominant capitalist relations. Examples of these practices that are still common today is the so-called "free contribution box" for financial support. In this case, the person who wants to get a product (coffee, drink, food) leaves any amount of money in the box at will.

The anti-commodity logic within the anarchist movement seems to have prevailed and shaped its conceptualisation of the economy. Namely, this anticommodity logic is another means, in the here and now, on the road to social revolution. In this light, anti-commodification practices have become a criterion that defines the level of conflict with the State and the capitalist system that a certain group practice. In other words, the more efforts are made to overcome the economy through anti-commodification practices, the broader the scope of the conflict for change of the political structure.

This has led to the marginalisation of certain aspects of collective action, in which the element of conflict does not focus on anti-commercial action, but 
instead on alternative production and an alternative economy. Moreover, these critiques argue that since alternative economic practices reproduce the market and currency and that since they have not chosen to abolish commodities, they are doomed to become integrated and fail due to the domination of capitalism.

In this paper, we index and categorise the critical narratives that have developed regarding certain active SCE enterprises that attempt to highlight an alternative in the field of production and the economy. The specific critiques have been indexed and divided in terms of their economic and political dimensions as seen in Table 2. This categorisation was made because economic criticism focuses on issues of capital reproduction, while political criticism focuses on issues of political identity.

Table 2. Economic and political dimensions of anarchist critique to the fields of "Solidarity and Cooperative Economy"

\begin{tabular}{|l|l|}
\hline \multicolumn{1}{|c|}{ Economic dimension of criticism } & \multicolumn{1}{c|}{ Political dimension of criticism } \\
\hline 1) Non-challenge of capital & 1) The individual is a capitalist \\
\hline 2) Compliance with market laws & $\begin{array}{l}\text { 2) Repression of the class } \\
\text { struggle }\end{array}$ \\
\hline $\begin{array}{l}\text { 3) Promotion by the State and } \\
\text { the EU. }\end{array}$ & $\begin{array}{l}\text { 3) It is an individualistic survival } \\
\text { solution }\end{array}$ \\
\hline $\begin{array}{l}\text { 4) Financial capital is required in } \\
\text { order to start }\end{array}$ & $\begin{array}{l}\text { 4) Promotes political withdrawal } \\
\text { and demobilisation }\end{array}$ \\
\hline
\end{tabular}

\section{Analysis and Results}

\subsection{Economic dimension of criticism}

Critiques developed from a strictly economic perspective emphasise on the reproduction of capital and the extraction of surplus value. In the case of Thersitis (Thersitis 2014, 10-14; PfA 2012), the critique focuses on the inability of alternative cooperative ventures to challenge capitalism since they themselves participate in the reproduction of commodity relations. According 
to this perspective, radical anti-capitalist ventures that seek to challenge and break ties with the domination of capitalism, need to focus on the capitalist structure (social and economic) and, especially, against the process of the constitution of commodity relations. As opposed to most existing cooperative ventures that commodify the human need for entertainment, social gatherings, communication, and nutrition becoming part of the market economy and the dominant production and distribution of goods.

In addition, SCE enterprises exist under a regime of compliance with the laws of the market, which results in conditions conducive to their gradual transformation into capitalist enterprises.

According to the critique coming from Contra (Contra 2013), the logic of the market imposes competition by its nature, resulting in the following dilemma plaguing enterprises operating in the field of alternative economy: either to attempt the self-management of labour in a context of poverty and self-exploitation, through low wages and many hours of unpaid labour, or to be transformed into a capitalist enterprise in which the bosses set their own rules. The above critique refers to specific cases of cooperative enterprises that did indeed follow one of the aforementioned routes. In addition, it showcases the assumption that the expectation of an enterprise to be profitable is part of the logic of competition and, importantly, in order to be able to create profit and be competitive within the market, they have to exploit their own work force. This business logic leads to instances of recruitment of new employees when the profits are enough and lay-offs when they are not.

Furthermore, the economic dimension of the critique emphasises that SCE projects are promoted by state policies with the simultaneous and support and stir of the European Union. This support framework, according to the particular critique of three groups (Eleutherokkokos 2014; Thersitis 2014, 7; Contra 2013), is based on a more general restructuring of capitalism with the aim of establishing a hybrid welfare model within neoliberal recession programs. Therefore, these critiques consider the inclusion of cooperative enterprises in the institutional framework enforced by the State in 
order to reaffirm the dominant capitalist interests, while, at the same time, strengthening them directly or indirectly through the repayment of taxes.

Another critique (Thersitis 2014, 15; ESE 2014) developed concerning the economic field focuses on the issue of financing for the creation of SCE enterprises. One part of this critique acknowledges and supports the cases where companies are recovered and self-managed by employees and, thus, in which the enterprises have arisen through subversive grassroot processes. This argument represents the radical logic of expropriation of both the means of production and private property. On the contrary, cooperative enterprises that were not the result of grassroot movements and struggle, but require specific individual funds in order to start exclude individuals who do not have the required capital. This view supports the notion that cooperative enterprises are not decolonised fields of capitalist relations since their creation lies in the coalition of individual capital.

Finally, there is also the critique (Thersitis 2014, 10) focusing on cooperative enterprises active mainly in the food market and the trade of mass-produced products, which are derivatives of human-to-human exploitation. This criticism highlights cases in which, while SCE enterprises promote an ethical and fair economy and production, they simultaneously trade with and use products of multinational capitalist companies. In this context, the critical perspective notes that the need for financial sustainability of the enterprise and existing market competition leads cooperative enterprises to be trapped in the reproduction of dominant productive exploitative relations.

\subsection{Political dimension of criticism}

Apart from the economic dimensions that focus on the inability of "Solidarity and Cooperative Economy" to challenge the capitalist economic structure, there are also critiques concerning the political dimension.

One of the most widespread critiques revolves around the issue of "class suicide" (Contra 2013). This concept states that, since SCE reproduces commodity and commercial relations, it results in the extinction of a whole 
class. This argument posits that not only a dependent employment relationship is present in SCE, but at the same time the individual themselves is a capitalist. In other words, this particular critique links the contribution of this alternative economy to the disappearance of the working class.

The above argument has reinforced stipulations that under this condition the processes of class struggle and conflict are repressed. Once the individual is considered self-employed and a partner of the enterprise, she ceases to occupy their original class position and she is more concerned with the more efficient management of capital. Based on this reasoning, the individual is no longer interested in class conflicts, since her identification with the business model of the partner of an enterprise, does not allow her to reflect on issues of labour and shake off and the ideology of private property (Thersitis 2014, 15).

Another point of criticism (WaU 2013) is the one that notes that the choice of an individual to work in the field of "Solidarity and Cooperative Economy" is a purely an individualistic solution for survival. In a rather fluid environment created by the generalised crisis, the sense of insecurity and precarious work propels individuals to isolate themselves and seek solutions and activities able to create a sense of individual security rather than collectivisation. For those critics, SCE is an economic field established with the aim to defend the standard of living of a small group of people.

Lastly, there is a critique that highlights that- due to the large workload that self-managed work creates for the individual- it ultimately results in the creation of conditions that result in the demobilisation of social movements (Thersitis 2010, 15; WaU 2013). Namely, the amount of time that is required for management duties causes difficulties for many cooperative enterprises with regards to being effective and productive. Subsequently, lack of time deprives individuals of opportunities to engage in political and social struggles in the context of broader movement processes. As a result, individuals choose to demobilise and keep within the isolated of their own collaborative practices and microcosm. 


\section{A brief analysis of critical approaches}

It can be easily inferred that the aforementioned points of critique were not published in order to initiate a dialectical process with the projects of "Solidarity and Cooperative Economy". They seem to express an ideologically dogmatic anti-capitalist content. This stance, in combination with the exclusion of cooperative enterprises from wider repertoires of collective action, creates rather large gaps between different ideological perspectives of the anti-capitalist movement in Greece. These critiques are reinforced in cases where collaborative ventures have failed in terms of social and economic viability.

However, by looking carefully at both the economic and political dimensions of specific critiques, we note the individualistic conceptualisation that permeates them (Psimitis 2018) in the case of anti-commodity logic. From the argument focusing on the "reproduction of capital" to the one putting its emphasis on the "class suicide", it is clear the reasoning is shaped through an individualistic lens. In essence, they view each person working in such an enterprise as an individual in wage labour. According to this view, wage labour is embedded in a structure of a contract between the worker and the capitalist. Therefore, based on this approach, social practices cannot be extended beyond the strictly exclusive relationship of the subject with the means of production.

However, within such enterprises each individual seems to have other direct social relationships, obligations, and commitments on which she depends and through which a wide range of daily social practices is reproduced. This means that an invisible galaxy of actions and relations develops inside and outside the social and political environment of the enterprise which are both within and beyond the boundaries of dominant capitalist relations. These relationships are not taken into account when shaping these arguments.

Considering that these social relations of interdependence emerge in fluid environments of humanitarian, economic, social and political crisis, the primary concern refers to the transformation that these relationships need to 
undergo. From this perspective, SCE is viewed as a field of redefining social relations, since the forms of exploitation of labor, political oppression, and cultural domination are challenged in practice (Mance 2011). This transformation and attainment of new content in social relations is achieved through the principles of direct participation and democracy (Laville 2010).

The critiques that focus on the inability of SCE to challenge the reproduction of capital and the exploitative relations should also be explored in cases where cooperative networks, which base the reproduction of economic value on a cyclical process of economy, distribution and consumption, have been developed. Within these alternative networks, an attempt is made to transform the relationship between economy and society on the basis of trust, reciprocity, redistribution and community development (Nardi 2012). Unfortunately, such networks have not been developed extensively in Greece compared to Latin American countries, which have a tradition in the social practices of communism. More specifically, as Mance $(2002,7)$ notes, within the boundaries of these cooperative networks, products and services -consumed both inside and outside the network -are produced with the ultimate objective of increasing the autonomy of the respective network from capitalist production and economy. The creation of new job vacancies and ventures that meet the needs of the network is based on the collective reinvestment of surpluses following social criteria and the provision of economic conditions. This cyclical process seems to contradict the dominant linear reproduction of capital and is not influenced by market rules.

Regarding the necessary initial capital for the creation of a cooperative venture, it is a fact that this stands as a very serious problem. The required capital is proportional to the particular features and the operational domain of the project. For instance, land as well as specialised machinery for production may be required. This limiting factor is a real situation that the people behind cooperative enterprises have had to deal with. Therefore, respective critiques attempt to equate non-possession of capital with the exclusion of individuals from participating in a cooperative enterprise. This rationale, however, contradicts the collaborative viewpoint that permeates 
such projects as well as their political stance towards direct action and participation. The SCE ventures usually give significant value to concepts such as solidarity and mutual aid in the political sense of building first a companionship and then an ecosystem beyond the dominant limits of the capitalist mode of organisation (Satgar 2018). This critique of the equating inequality with exclusion is therefore reflecting the environment governed by the values that signify the existence and identity of the collaborative venture itself.

The critique characterising the involvement of an individual in a cooperative project as a personal solution, connecting it with his demobilisation from social movements, is in contrast with the qualitative features of the time period and the quantitative increase of projects that follow the principles of "SCE. Both disengagement and participation in social movements, as phenomena of collective action, are related to the characteristics that define the political, social and economic environment each time period.

In Greece, the historically condensed period from 2008 onwards was marked by the massive revolt of December 2008, innumerable (violent and non-violent) rallies, occupations of public spaces and diverse repertoires of action that seem to have reached their limit at the moment. There is a need to explore and expand these limits within the processes of the grassroot movements in order to enhance unmediated social struggles. The limits indicate the point where the means and goals of social movements need to be re-determined by exploring new content and new collective actions and practices. This reflective process might help to overcome the established criticisms that persist in a kind of determinist conflict at the core of anticommodity culture. This conflict marginalises alternative economic and practical endeavours which may be of strategic importance for social movements that struggle for social transformation.

To conclude, the critiques explored in the present study are represented by a part and not by the whole anarchist movement. However, this argumentation seems to have formed a discourse which ignores the 
connection of social movements with "Solidarity and Cooperative Economy". This leads to the creation of a conceptual binary of two opposite movement poles: the rupture with capitalism (anti-capitalist movement) and the assimilation with it (the Solidarity and Cooperative Economy). This bipolar conceptual scheme cultivates a political environment that resists linking "Solidarity and Cooperative Economy" with contents, forms and actions within the wider anti-capitalist movement and a key part of a grassroot movement.

\section{Discussion}

\section{The economy in the anarchist thought of Kropotkin, Proudhon and Bakunin}

Despite the fact that economics is a domain usually treated with scepticism by the anarchist movement, it is a known fact that it was a key issue of analysis in the early anarchist thought which was expressed mainly through three basic trends in the 19th century. To begin with, anarcho-communism, advocated by Peter Kropotkin, which proposes the emergence of a social system based on voluntary associations of self-governing communities and worker-run enterprises (Kropotkin 1970, 157). In anarcho-communism, there is no system of property or payroll, as access to goods is realised through the need determined by the ethics of mutual aid (Kropotkin 1976).

Another notion of paramount importance is mutualism (reciprocity), developed by Pierre-Joseph Proudhon, concerning a comprehensive economic venture of natural exchange under which new productive and economic institutions are constructed. These new institutions can operate alongside the rulers, acting as a form of alternative pressure and gradually acquiring the potential to abolish property and the State (Proudhon 2003). Last, but not least, the concept of anarcho-collectivism is related to the thought of Mikhail Bakunin and refers to a system of social organisation where the expropriation 
of State and private property ultimately achieves the reorganisation of production and the distribution of the means of production ${ }^{1}$.

Despite the existing, significant differences when it comes to the expression of the anarchist thought ${ }^{2}$, a key point of convergence between the respective theories developed by social anarchist thinkers is the conflict with the State and its institutions. Thus, it is easily decipherable that anarchist thinkers of the 19th century were seeking alternative proposals that would oppose the State and the capitalist system and were orientated towards collective self-determination and autonomy.

\section{Peter Kropotkin}

In particular, Kropotkin's concept focuses on social self-organisation, communitarianism and mutual aid. The Russian thinker, having the Paris Commune of 1871 as a model, attempted to examine the political organisation that would be required in order to include "this new historical period of freedom, equality and solidarity in the evolution of humanity..." (Kropotkin 2011, 73).

In his text "Modern Science and Anarchism" (Kropotkin 1976), he develops his views on the issue of social change. More specifically, he argues that social change is achieved due to the eternal conflict of two forces. This viewpoint also uncovers Kropotkin's geological and anthropological research interests, which were the main subject of his scientific studies and in part formed the core of his anarchist social theory. In this light, the Russian

\footnotetext{
${ }^{1}$ Bakunin was involved in the issue of revolution all his life. His writings are a synthesis of theory and applied practice. Due to the "practicality" of his writings, he himself did not return to his texts to actively reflect on them, thus failing to formulate a coherent anarchist theory. Instead, he wrote new texts and traveled to various cities in Europe, communicating his ideas in order to ultimately put them into practice. In this sense, we do not have a complete excerpt that emphasizes the issue of social organization. His close friend and comrade J. Guillaume attempts to compile Bakunin's thought, which focuses on the transition to an anti-authoritarian institutional society. In 1874, Guillaume completed the essay "Ideas on Social Organization" and two years later, in 1876, the year of Bakunin's death, he published it in his honor.

2 The theoretical distance between the thoughts of the three anarchist thinkers is based on different ontological perspectives that are crystallized mainly in the question of political organization. In particular, McLaughlin in his study "Anarchism and authority: A philosophical introduction to classical anarchism" (2007) attempts to redefine the relationship between anarchism and power. In his text, he distinguishes between Proudhon's psychocentric conception, Bakunin's naturalism, and Kropotkin's controlling approach.
} 
anarchist marks, on the one hand, the self-regulation of the masses through the "creative power(s) of the people..." (Kropotkin 2004, 6) and, on the other hand, he observes the existence of minorities that form alliances with each other, in order to dominate and "...keep (people) submissive and force them to work for the masters". For Kropotkin, anarchism is placed on the constructive and creative social side, offering new directions regarding the institutions of community life (Kropotkin 2004, 9).

In his work "Mutual Aid: A Factor of Evolution" (Kropotkin 2006), he attempts to highlight the importance of solidarity and cooperation in social transformation, through a composition including biological, anthropological, ecological and historical findings. As far as he is concerned, his belief in selforganisation and his opposition to authoritarian mechanisms are the dimensions of self-determination that subsequently unfold throughout the spectrum of his work. Through the proposed organisation that predominantly refers to economic and political decentralisation, self-government and free agreement (Kropotkin, 1985), Kropotkin's self-determination can be perceived as a kind of autonomy in motion both before and after the revolution (Kropotkin 2004, 17).

Kropotkin's thinking seems to be in agreement with the practices developed within "Solidarity and Cooperative Economy" in Greece. The emphasis on the organisational framework for a different economy and production through decentralised networks is a strategy that today's ventures are trying to follow. The alternative distribution network for Zapatista coffee that comes from the Lacandona jungle (Mexico) in Athens and then is distributed throughout Greece confirms the above wording. On the contrary, contemporary anarchist critiques seem to marginalise the economic organisation advocated by Kropotkin by condemning alternative economic endeavours within the capitalist system.

\section{Pierre-Joseph Proudhon}

As we proceed deeper in the anarchist thought, we come across Proudhon, who attempts to delimit anarchy as a mode of governance (Proudhon 1994, 
204-212) in his work "What is property". Considered by many as the founder of the theory of mutualism, he draws special attention to alternative organisational forms of economics beyond capitalism. Apart from that, he also criticised private property as a result of the character of the social contract that “...was pre-designed by Grotius, Montesquieu and J. J. Rousseau and was signed by the whole human race..." (Proudhon 2006, 23-24) and supported the idea that the State and the Church functioned as institutional forms of domination.

In particular, he proposes a federal political and economic organisation oriented towards the construction of social autonomy (Prichard, 2013). For Proudhon, the new social contract is based on the mutual and equal conciliation of society-community. As he characteristically states in his work "System of Economic Contradictions" a "...theory of reciprocity (is) a system of guarantees that absorbs the ancient forms of our political and commercial societies, that satisfies all the conditions of its effectiveness, progressiveness and justice...(is) a society not only compatible, but realistic that will turn the division into an instrument of science, that will eliminate the enslavement of machines and will prevent crises immediately upon their appearance, that will extract not only benefit from the competition, but also a guarantee of security for all deriving from the monopoly" (Proudhon 1983, 537).

Therefore, the French anarchist perceives reciprocity as the structural element according to which the political and economic organisation will be restructured. Proudhon's paradigm seeks to destroy exploitative structures based on an applied form of reciprocity that is crystallized through a system of self-government and self-organisation. This organisational structure expressed by Proudhon is governed by the principles of independence, equality, proportionality and justice (Sweger-Hollingsworth 2019) within a framework of natural exchange.

Proudhon seems to focus more on the processes required for a social and political transformation than on the revolution itself. The research on the implementation of his proposals was reinforced by the idea of mutual credit (Dodd 2014). More specifically, a year after the revolutions of 1848 taking 
place in various parts of Europe, Proudhon published "The solution of the social problem" [1849]. This is a partially applicable plan that summarises the thought of the French thinker through his proposal for the creation of two banks - A "transaction bank" and a "people's bank".

The "mutual-credit bank" refers to an institution of mutual exchange of credit for the benefit of the productive professions that are members of the bank. According to Proudhon's plan, each member has the option of interestfree lending with a type of an alternative banknote. The only obligation of the member is the deposit of the annual instalment to the bank based on the loan agreement (Proudhon 1927, 35-36). Proudhon's perception of money is reflected precisely in the way the proposed banking institution operates. With the exchange character of the bank, no capital is accumulated through interest; instead, a transaction flow is established based on reciprocity (Proudhon 1927, 36).

Except for the "mutual-credit bank" which was never actually completed, Proudhon also put forward his proposition for a "people's bank". He founded the bank in January 1849 along with other French utopians, including Lechevalier ${ }^{3}$. The differences between the two banking institutions were great, mainly due to the practical needs of viability concerning the "people's bank". More specifically, the "people's bank" required capital to cover fixed needs. Therefore, it began its activities with accumulated capital as well as lending at a very low interest rate. The requirements of this project quickly turned it into a joint venture with a general manager and a board. Within a few months, it had managed to have more than 13,000 members, but very limited capital for lending. Under these circumstances, the bank closed, while, at the same time, Proudhon was persecuted and imprisoned, because of his strong criticism towards the regime of Louis-Napoleon Bonaparte, mainly through the newspapers of the time.

\footnotetext{
3 Jules André Louis Lechevalier (1806 - 1862) was a French utopian socialist, economist and anthropologist. He was influenced by Proudhon and distanced himself from Fourier's French utopianism. He has been recognized as a forerunner of the French welfare system and a pioneer of the theories of international development and community microeconomics.
} 
Undoubtedly, Proudhon's thought and practices are oriented towards an autonomous direction of social and economic reform (Lioveras et al. 2019). He focused on the shift of the economy from the capitalist class to the workers themselves both in theory and in practice. In particular, Proudhon's paradigm could be accomplished through a framework of mutual credit and exchange within a self-governing community and federation. This collective dynamic has the potential to spread within the state structures until human exploitation is eliminated and ultimately it gives its place to a new society.

Proudhon's proposals are one of the first articulations in relation to an alternative social and economic basis that has its starting point in the freedom and autonomy of society (Vieta 2014). To this end, we can also see the integration of SCE into Proudhon's broader thinking. It is essentially an early framework for organising cooperative work characterised by equality, freedom and democracy.

The values of reciprocity are found in the organisational practices of the alternative ventures and networks they seek to create. At the same time, the emphasis on organising processes for social transformation is part of the perception of activists involved in the field of "Solidarity and Cooperative Economy". On the other hand, the critiques produced by the Greek anarchist movement seem to deviate from Proudhon's logic, mainly because he does not focus directly on the question of revolution.

\section{Mikhail Bakunin}

Influenced by Proudhon's thinking, Bakunin also advocated a kind of a federal system of social and political organisation. He perceived the institution of the State as one of the key institutions hindering the development of collective freedom. As he states in his text "God and the State" "The State is not identical with society, it is only a primitive and at the same time an abstract historical form of it...The State is the authority, the source of violence...it is by nature the legal rapist of the will of people, the constant denial of their freedom..." (Bakunin, 1986:106). The anti-state convictions of the Russian anarchist led him to simultaneously oppose the institution of the Christian church, as he 
expressed a denial of any kind of sovereignty that undermines the "...human light...the only thing that can emancipate us, give us dignity, freedom, happiness..."(Bakunin 1986, 36).

One can easily understand through the extracts cited above that the issue of freedom seems to be of particular concern to Bakunin. More specifically, the Russian anarchist approaches the issue of freedom by placing emphasis on the dynamics of collectivism. Through the social and relational content of freedom, he highlights the natural society, as opposed to the artificial society of the State, which is governed by customs, manners, traditions and moral rules formed over the years (Dolgoff 1971, 6).

However, Bakunin does not equate natural society with freedom. As he notes, social tyranny often emerges in natural societies. More specifically, "...social tyranny, which is often fatal and depressing, does not assume the imperatively violent character of the legitimate and formalized despotism that characterizes the power of the state. It is not imposed in the form of a law to which every person is obliged to submit, in order to avoid legal sanctions..."(Bakunin 1986, 104). For Bakunin, therefore, a natural society can be either beneficial or harmful, depending on the moral, spiritual and material level of its members. In this sense, Bakunin's question about a natural society is the content of the practices that can potentially be developed.

In "Ideas on Social Organisation"4 [1876], Guillaume, Bakunin's comrade, summarises the discussions that took place in the anti-authoritarian sections of the International Workers' Union (First International) [1864-1876] based on Bakunin's central thought. The small sections of the text include topics related to social organisation. Issues such as production, economy, housing, education, health and security are among some of the key contents of the debates among the collectivist anarchists of the period.

Bakunin's central idea regarding a liberal social organisation revolves around labour and cooperative unions within federal communities. The realisation of this design is developed in three stages. Producers first need to

\footnotetext{
${ }^{4}$ The text "Ideas for Social Organization" has been translated from Russian into English by Sam Dolgoff and is included in his book "Bakunin on Anarchy. Selected Works by the Activist-Founder of World Anarchism" (1971) entitled "On building the new social order".
} 
"...create a community structure so as to sell or exchange their products..." (Dolgoff 1971, 360). This community structure can then facilitate the sharing of tools and machinery to "... (the producers) assist each other in performing demanding tasks that are best achieved when realized by a large team" (Dolgoff, 1971: 360). In the end, "...collective work will naturally lead to collective ownership. An agricultural collective can frame an entire community [autonomous regional unit] and, if it is economically necessary in terms of efficiency and greater production, can embrace many communities..." (Dolgoff 1971, 360).

From this perspective, the Russian revolutionary observes the first dynamics of a collective labour action in the direction of economic and social emancipation in these workers' unions and cooperatives.

In this conceptual framework we could also categorise the cooperative networks which, although still in their infancy, try to produce for the needs of the community to which they belong. One attempt of a network of cooperative enterprises in Greece is the organising of the 1st and 2nd Co-open Air festivals that took place in 2018 and 2019 respectively at the recovered factory VIOME in Thessaloniki. The festivals were an opportunity for the participating enterprises and individuals to meet, exchange experiences, help each other, and communicate their social practices and build on their decentralised and independent network.

However, despite the fact that Bakunin's theory and thinking is very popular in the Greek anarchist movement, an anarcho-collectivist section has not formed mainly because of the rejection of the market and money as a possible field of activity and political organisation.

Undoubtedly for the classical social anarchists Kropotkin, Proudhon and Bakunin, the concept of autonomy, although not explicitly mentioned in their texts, is a concept inextricably linked to that of freedom. In the case of anarchist social thinkers, autonomy is introduced through collective selfgovernment, prophetically raising the issue of decolonisation (Guerin 1973, 77). The core of thought, especially with regard to the applied dimension of collective transformational practices, seems to display common features 
concerning the organisation of production and the economy. These commonalities are concentrated around the following axes: a) possession and not property, b) the socialisation of the means of production and c) the free federation.

To sum up, social anarchist thinkers perceive local units, groups, collectives, and ultimately the whole society as a social potential that can only be developed within a framework of self-organised and self-managed coordination. Federal organisation for autonomy in all areas of social life is an alternative to the suffocating central state, and towards the revolution and the formation of future societies.

In this regard, the action of activists involved in SCE projects is a process of reterritorialisation, it maintains ties with the community, and it is prefigurative (Psimitis 2017). These characteristics can be incorporated into classical anarchist thought that focuses on collective self-determination against the State and its institutions. However, the anarchist space in Greecein a context of voluntarism, where the will and the aim of the abolition of the State and capitalism is entirely reflected in political organisation, results in outburst of social mobilisation, conflict, and revolt such as the December 2008 uprising which are dominated due to their organisational spontaneity and because there is no room for reflection on issues of political, economic and social organisation. The practices of economic organisation developed within SCE cannot be excluded from the movement strategies for social transformation.

\section{Conclusions}

Self-management: A radical approach to the issue of the "Solidarity and Cooperative Economy"

We have outlined above how classic anarchist thought posed the question of economic and productive organisation since the very beginning in an attempt 
to construct its revolutionary discourse against the State and the capitalist system.

At the same time, anarchist thought emerged as an alternative way of organising, separate from the Marxist conceptual form of seizing power seizure and, ultimately, social transformation through the State. The example of the Spanish Revolution shed light on the different approaches that insurgents and revolutionaries can pursue.

The process of collectivisation of Spain was one of the most important experiments of the 20th century and was the culmination of the anarchist influence in Spain since anarchist Giuseppe Fanelli introduced Bakunin's ideas to intellectuals and workers in Barcelona and Madrid in the 1870s. The anti-authoritarian structures that emerged during the Spanish Revolution expressed a combination of the collectivist tradition familiar to the Mediterranean countries, the industrial economy and the urbanised society (Bookchin 1974: 12). It was a revolutionary process in which private property and individual ownership of the means of production were replaced by collective property (Onejero 2010). The phenomenon of collectivisation in Spain showed that the anarchist ideas on which it was based could in practice create innovative structures of social organisation during the interwar period where the rise of authoritarian and nationalist regimes led to the vortex of World War II.

Through this historical perspective, one might argue that the critical issue for the contemporary anarchist movement is the way in which it will attempt to adjust and apply the means at its disposal in order to answer the question of social change. Traditional approaches seem to be in crisis and the need for social change is critical at a time when the barbarity of capitalism in both nature and humanity is having a more destructive effect than ever (Taibo 2018, 147).

Considering this, the anarchist movement needs to employ its basic tools towards this direction, which essentially are preparation, direct action, economic and political autonomy, education and the convergence of theory with practice (Graeber 2002). This is a process that requires experimental 
models to be implemented in a wide range of social activities beyond, in parallel, and in open conflict with the capitalist mode of organisation.

By observing the historical instances (both older and contemporary) when the anarchist movement has been able to experiment and implement some of these principles, we note that self-management plays a rather crucial role in this process of social redetermination (Böhm et al. 2010; Pickerill and Chatterton 2006). The term "self-management" comes from the SerboCroatian word "samoupravlje", which first appeared in the French literature in the 1960s to describe the Yugoslav system of self-management put in practice by the Tito regime in the Socialist Federal Republic of Yugoslavia. It has since been introduced into the terminology of social movements to describe social practices expressed through demands and social struggles depending on the political and social context. The range of movements highlighting the meaning of the particular term is wide. From organised labour struggles to struggles concerning gender issues, health, the environment and occupied spaces, the term "self-management" signifies social practices with horizontal democratic and participatory processes (Milan 2020, 260).

Some of the groups and enterprises that are active in the field of "Solidarity and Cooperative Economy" in Greece include self-management in their practices. All of these practices are processes of social transformation that take place in a context of shared experiences and solidarity; they aim at the formation of a counter-proposal regarding the organisation of labour and production (Elsen 2018; North and Cato 2017; Gibson-Graham 2014; 2008; 1996). In other words, these types of social and economic organisation that reproduce social relations based on collective aims and interests, have an educational dimension, while they, at the same time, attempt to be constructed in an autonomous direction that directly contradicts the capitalist model (Kioupkiolis and Karyotis 2015). It is a kind of prefigurative politics around the field of economics and production that entails collective experimentation, imagination and creativity, and the creation of new rules and the social 
dissemination of these practices as an alternative/ anti-capitalist solution both in the present and in the post-capitalist future (Yates 2014).

Therefore, the contemporary anarchist movement in Greece might need to focus more on the field of "Solidarity and Cooperative Economy" from a perspective of creation, networking and communication between political collectives and self-managed work ventures and structures. The political stance regarding the re-ownership of the entirety of people's lives back from the State and its mechanisms requires an anti-capitalist framework that includes dynamic manifestations of a competitive political proposal about the organisation of all aspects of life as well as political action.

"Solidarity and Cooperative Economy" functions in two dimensions related to this point. On the one hand, it functions as a theoretical and practical framework of the principles of self-management and autonomy, in the sense that it guides the construction of symbiotic productive and economic communities that are necessary for social transformation. At the same time, along with other self-managing groups and initiatives, it is one of the most important fields where application and experimentation with this particular intersection of ideas can happen. The social practices developing within the space of alternative economy are currently in a state of identifying new ways of solidarity and collective coexistence. Hence, this research speaks to an unmediated and horizontal field of activity and action in which present activity plays a leading role in shaping the development and future implementation of these ideas. This dual dimension indicates the convergence of "Solidarity and Cooperative Economy" with anarchist thought. This is because Representative Democracy and dominant economy structures are being challenged in practice through a counter-proposal for a radical participatory democracy based on self-management. In this context, the question that needs to be explored is the way in which political collectives, self-management structures and the projects and enterprises of the "Solidarity and Cooperative Economy" attempt to exchange and communicate their concerns with a view to a broader communication of the notion of social and political transformation. 


\section{References}

Andretta, Massimiliano, Donatella Della Porta, Lorenzo Mosca, and Herbert Reiter. 2003. No global-new global. Soziale Bewegungen und Globalisierung, Frankfurt am Main: Verlag.

Bandy, Joe and Jackie Smith. 2005. Coalitions across borders:Transnational protest and he neoliberal order. Lanham, MD: Rowman \& Littlefield.

Bakunin, Michael. 1986. God and the State. Athens: Eleftheros Typos. (in Greek). Böhm, Steffen, Ana C. Dinerstein, and André Spicer. 2010. “(Im)Possibilities of Autonomy: Social Movements in and beyond Capital, the State and Development." Social Movement Studies 9 (1): 17-32. https://doi.org/10.1080/14742830903442485.

Bosi, Lorenzo, Marco Giugni, and Katrin Uba. 2016. “The Consequences of Social Movements: Taking Stock and Looking Forward." In The Consequences of Social Movements, edited by Lorenzo Bosi, Marco Giugni, and Katrin Uba, 3-38. Cambridge: Cambridge University Press. https://doi.org/10.1017/CBO9781316337790.001.

Contra. 2013. "Self-management: A Labor Liberation or another bait in the Capitalist trap?" Contra, April 25, 2013. https://rb.gy/6o5bzi. (in Greek).

Chloupkova, Jarka. 2002. "Czech Agricultural Sector: Organisational Structure and Its Transformation," 22.

D'Anieri, Paul, Claire Ernst, and Elizabeth Kier. 1990. "New Social Movements in Historical Perspective." Comparative Politics 22 (4): 445. https://doi.org/10.2307/421973.

Porta, Donatella della. 2005. "Deliberation in Movement: Why and How to Study Deliberative Democracy and Social Movements." Acta Politica 40 (3): 336-50. https:/ / doi.org/10.1057/palgrave.ap.5500116.

Porta, Donatella della, and Sidney Tarrow. 2012. “Interactive Diffusion: The Coevolution of Police and Protest Behavior with an Application to Transnational Contention." Comparative Political Studies 45 (1): 119-52. https:/ / doi.org/10.1177/0010414011425665.

Della Porta, Donatella. 2020. "Building Bridges: Social Movements and Civil Society in Times of Crisis." VOLUNTAS: International Journal of Voluntary and Nonprofit Organizations 31 (5): 938-48. https:/ /doi.org/10.1007/s11266-020-00199-5.

Dodd, Nigel. 2014. The social life of money. Princeton, New Jersey: Princeton University Press.

Dolgoff, Sam. 1971. Bakunin on Anarchy: Selected Works by the Activist-Founder of World Anarchism. New York: Vintage Books. 
Dolgoff, Sam and Murray Bookchin. 1974. The Anarchist Collectives Workers' Self-management in the Spanish Revolution 1936-1939, New York: Free Life Editions.

Elsen, Susanne. 2018. “Community Based Solidarity Economy and Eco-Social Transformation" 8 (1): 19.

ESE (Liberal Trade Union). 2014. "Regarding the alternative economy." April 26, 2014. https://rb.gy/k8ckkp. (in Greek).

Freedom Routre. 2014. "Alternation: Another world is not possible!" Freedom Routre, November, 2014. https://rb.gy/iz5m9d. (in Greek).

Fuller, Jack. 2001. "The new workerism. The politics of the Italian autonomists." International Socialism 92 (2). https://www.marxists.org/history/etol/newspape/isj2/1980/no2008/fuller.html

Gaiger, Luiz Inácio. 2017. "The Solidarity Economy in South and North America: Converging Experiences." Brazilian Political Science Review 11 (3). https:// doi.org/10.1590/1981-3821201700030002.

Gibson-Graham, J. K. (1996). The end of capitalism (as we knew it). Oxford: Basil Blackwell.

Gibson-Graham, J. K. 2008. “Diverse Economies: Performative Practices for 'other Worlds'." Progress in Human Geography 32 (5): 613-32. https://doi.org/10.1177/0309132508090821.

Gibson-Graham, J. K. 2014. "Rethinking the Economy with Thick Description and Weak Theory." Current Anthropology 55 (S9): S147-53. https://doi.org/10.1086/676646.

Gritzas, Giorgos, and Karolos Iosif Kavoulakos. 2015. Alternative economic and political spaces. Social movements and spatial development. Athens: Kallipos.

Gritzas, Giorgos, and Karolos Iosif Kavoulakos. 2016. "Diverse Economies and Alternative Spaces: An Overview of Approaches and Practices." European Urban and Regional Studies 23 (4): 917-34. https://doi.org/10.1177/0969776415573778.

Graeber, David. 2002. “The new anarchists." New Left Review (13): 61-73.

Guérin, Daniel. 1973. Anarchism. From theory to practice. Athens: Eleftheros Typos. (in Greek).

Guillaume, James. 1876. Ideas on Social Organization. https://rb.gy/ay7lpw

Jasper, James M. 2010. "Social Movement Theory Today: Toward a Theory of Action?: Social Movement Theory Today." Sociology Compass 4 (11): 965-76. https://doi.org/10.1111/j.1751-9020.2010.00329.x.

Karyotis, Theodoros and Kioupkiolis Alexandros. 2015. "Self-managing the commons in contemporary Greece." In An alternative labour history: 
worker control and workplace democracy, edited by Dario Azzellini, 298328. London: Zed Books.

Kontogeorgos, Achilleas and Panagiota Sergaki. 2015. Principles of the management of agricultural cooperatives. Challenges and prospects. Athens: Kallipos. (in Greek).

Kropotkin, Peter. 1970. Revolutionary pamphlets. New York: Dover publications.

Kropotkin, Peter. 1976. Mutual aid. A Factor of Evolution. Boston: Porter and Sargent Publishers.

Kropotkin, Peter. 1985. The conquest of bread. London: Elephant editions.

Kropotkin, Peter. 2004. Modern Science and Anarchism. Athens: Eleftheros Typos. (in Greek).

Kropotkin, Peter. 2011. The Paris Commune. Athens: Eleftheros Typos. (in Greek).

Laville, Jean-Louis. 2010. "The Solidarity Economy: An International Movement." RCCS Annual Review (2): 1-39. https://doi.org/10.4000/rccsar.202

Lloveras, Javier, Gary Warnaby, and Lee Quinn. 2019. “Mutualism as Market Practice: An Examination of Market Performativity in the Context of Anarchism and Its Implications for Post-Capitalist Politics." Marketing Theory, 20(10): 1-21. https:/ / doi.org/10.1177/1470593119885172.

Mance, Euclides André. 2002. "Solidarity-Based Cooperation Networks." IfiL. Curitiba.

Mance, Euclides André. 2011. "Solidarity Economy." IfiL. Curitiba.

McLaughlin, Paul. 2007. Anarchism and Authority: A Philosophical Introduction to Classical Anarchism. Abingdon: Routledge.

Milan, Chiara. (2020). “Beyond Europe: Alternative visions of Europe amongst young activists in self-managed spaces in Italy." European Journal of Cultural and Political Sociology, 7(3): 242-264. https://doi.org/10.1080/23254823.2020.1794922.

Moulaert, Frank, and Oana Ailenei. 2005. "Social Economy, Third Sector and Solidarity Relations: A Conceptual Synthesis from History to Present." Urban Studies 42 (11): 2037-53. https:// doi.org/10.1080/00420980500279794.

Nardi, Jason. 2012. How to weave solidarity economy networks. Experiences in Italy and other countries. Solidarische Okononomie Forum, Kassel: Rippes.

North, Peter and Molly Scott Cato. 2017. Towards just and sustainable economies: The social and solidarity economy North and South. Bristol: Policy Press. 
Novaes, Tahan- Henrique. 2013. “Foundations of Self-Managed Socialism: The Contribution of István Mészáros." In Cooperatives and Socialism, edited by Piñeiro- Camila Harnecker, 143-163. London: Palgrave Macmillan.

Novy, Johannes, and Claire Colomb. 2013. "Struggling for the Right to the (Creative) City in Berlin and Hamburg: New Urban Social Movements, New 'Spaces of Hope'? Debates and Developments." International Journal of Urban and Regional Research 37 (5): 1816-38. https://doi.org/10.1111/j.1468-2427.2012.01115.x.

Ovejero, Anastasio. 2010. "Spanish Libertarian Collectives: A Unique Historical Case of Worker Self Management" WorkingUSA 13 (4): 52135. https:// doi.org/10.1111/j.1743-4580.2010.00309.x.

Partnership for Anarchy. 2012. "Let's deny that it belongs to domination because it destroys what is beautiful in the world (A critique of selfmanagement)." In 2 texts from the alliance for anarchy, edited by Partnership for Anarchy, 11-17. https:/ / rb.gy/aluglq. (in Greek).

Polletta, Francesca. 2014. “Is Participation Without Power Good Enough? Introduction to 'Democracy Now: Ethnographies of Contemporary Participation.'" The Sociological Quarterly 55 (3): 453-66. https://doi.org/10.1111/tsq.12062.

Prichard, Alex. 2013. Justice, Order and Anarchy: The International Political of Pierre-Joseph Proudhon. Abingdon: Routledge.

Proudhon, Pierre-Joseph. 1983. System of economic contradictions or the philosophy of misery. Athens: Anagnostidi. (in Greek).

Proudhon, Pierre-Joseph. 1994. What is Property? Edited by Donald R. Kelley and Smith G. Bonnie. Cambridge Texts in the History of Political Thought. Cambridge University Press.

Proudhon, Pierre-Joseph. 2003. General Idea of the Revolution in the Nineteenth Century. New York: Dover Publications Inc.

Proudhon, Pierre-Joseph. 2006. About property. Thessaloniki: Katsanos. (in Greek).

Psimitis, Michalis. 2011. “The Protest Cycle of Spring 2010 in Greece." Social Movement Studies $10 \quad$ (2): $191-97$. https://doi.org/10.1080/14742837.2011.562365.

Psimitis, Michalis. 2016. "Collective Identities Versus Social Exclusion: The December 2008 Greek Youth Movement." In Urban and Regional Social Movements, edited by Christy Petropoulou, Anthina Vitopoulou and Charalampos Tsavdaroglou, 67-93. Thessaloniki: Invisible Cities

Psimitis, Michalis. 2018. "Critique of Marxist Criticism in the Solidarity Economy." In Aspects of the Greek crisis. Conflict cycle of protest and 
institutional outcomes, edited by Nikos Serdedakis and Stavros Tombazos, 521-46. Athens: Gutenberg. (In Greek).

Psimitis, Michalis. 2017. Social movements in everyday life: Identity, solidarity and prefiguration in contemporary 'cosmopolitan communities'. Thessaloniki: Tziola, (in Greek).

Raynaud, Philippe. 2008. The mosaic of the far left. Athens: Polis (in Greek).

RIPESS. 2015. "Global Vision for a Social Solidarity Economy: Convergences and Differences in Concepts, Definitions and Frameworks." Manila.

Andrés Ruggeri. 2014. Recovered Argentine Business. We occupy, we resist, we produce. Thessaloniki: Drifting Cities (in Greek).

Ruggeri, Andrés, and Marcelo Vieta. 2015. “Argentina's Worker-Recuperated Enterprises, 2010- 2013: A Synthesis of Recent Empirical Findings." The Journal of Entrepreneurial and Organizational Diversity 4 (1): 75-103. https://doi.org/10.5947/jeod.2015.005.

Satgar, Vishwas. 2018. "The Climate Crisis and Systemic Alternatives." In The Climate Crisis: South African and Global Democratic Eco-Socialist Alternatives, edited by Vishwas Satgar, 1-27. Johannesburg: Wits University Press.

Seferiadis, I. Seraphim. 2006. "Conflict politics, collective action, social movements: a reflection." Hellenic Review of Political Science 27: 7-42 (in Greek).

Shaffer, Jack. 1999. Historical dictionary of the cooperative movement. New Jersey: Scarecrow Press.

Somerville, Jeniffer. 1997. "Social movement theory, women and the question of interests." Sociology, 31(4): 673-95.

Soto Alarcón, Jozelin María and Chizu Sato. 2019. “Enacting peasant moral community economies for sustainable livelihoods: A case of womenled cooperatives in rural Mexico." World Development, 115: 120-31.

Souzas, Nikos. 2015. Stop talking about death my baby. Politics and culture in the competitive movement in Greece (1974-1998). Thessaloniki: Nautilus.

Sweger-Hollingsworth, Lauren. 2019. "Proudhon, Bakunin and Anarchosocialism." Economics Working Paper, Portland State University, (5):1-18.

Taibo, Carlos. 2018. Rethinking Anarchy: Direct Action, Autonomy, SelfManagement. Translated by The Autonomies Collective. United Kingdom: Ak Press.

Thersitis, Area of intrigue and overthrow. 2014. "A text criticizing the solidarity economy." January, 2014. https://rb.gy/qyktkk. (in Greek).

Vieta, Marcelo. 2014. "The stream of self-determination and autogestión: Prefiguring alternative economic realities." Ephemera, 14(4): 781- 809. 
Williams, Raymond. 2005. "Base and Superstructure in Marxist Cultural Theory." In Problems in Materialism and Culture, edited by Raymond Williams, 31-49. London: Verso.

Workers and Unemployed from the book domain. 2013. "Are meanings relativized in dark times? A critical approach to self-managed ventures." Skya, Jule 11, 2013. https://rb.gy/hzyzlj. (in Greek).

Yates, Luke. 2015. "Rethinking Prefiguration: Alternatives, Micropolitics and Goals in Social Movements." Social Movement Studies 14 (1): 1-21. https://doi.org/10.1080/14742837.2013.870883.

Zaimakis, Yiannis. 2018. "Autonomy, Degrowth and Prefigurative Politics: Voices of Solidarity Economy Activists amid Economic Crisis in Greece." University of Salento. https://doi.org/10.1285/I20356609V11I1P95. 